\title{
The South American lungfish Lepidosiren paradoxa as a new host for Trichodina quelenii
}

\author{
G. Pala ${ }^{a}$, T. H. V. Farias ${ }^{b}$ L. O. Alves ${ }^{b}$ and E. G. Lux Hoppe ${ }^{a *}$ \\ aDepartamento de Medicina Veterinária Preventiva, Faculdade de Ciências Agrárias e Veterinárias - FCAV, Universidade \\ Estadual Paulista - UNESP, Via de Acesso Prof. Paulo Donato Castellane, CEP 14884-900, Jaboticabal, SP, Brasil \\ ${ }^{\text {b} C e n t r o ~ d e ~ A q u i c u l t u r a ~ d a ~ U n e s p ~-~ C A U N E S P, ~ U n i v e r s i d a d e ~ E s t a d u a l ~ P a u l i s t a ~-~ U N E S P, ~ V i a ~ d e ~ A c e s s o ~ P r o f . ~ P a u l o ~}$ \\ Donato Castellane, CEP 14884-900, Jaboticabal, SP, Brasil \\ *e-mail: e.hoppe@gmail.com
}

Received: September 12, 2017 - Accepted: November 13, 2017 - Distributed: May 31, 2019

(With 1 figure)

\begin{abstract}
Recently, the South American lungfish Lepidosiren paradoxa is being found inside aquaculture ponds, and even though there are a few studies on their parasite fauna, there is still much to be reported. Thus, the objective of this study is to report parasitism by trichodinids in L. paradoxa, as these ciliate protozoa are related to injuries and mortality in fish farming. The lungfish were collected from experimental tanks, had their tegument scraped and the resultant mucus was analyzed under an optical microscope for morphological and morphometrical analyses in Giemsa and silver nitrate stained slides. The species found was identified as Trichodina quelleni. This is the first report of this parasite in L. paradoxa, and the second report in cultivated fish in Brazil.
\end{abstract}

Keywords: aquaculture, ectoparasites, invasive species, trichodinids.

\section{O lungfish sul-americano Lepidosiren paradoxa como novo hospedeiro para Trichodina quelenii}

\section{Resumo}

Recentemente, o peixe pulmonado sul-americano Lepidosiren paradoxa tem sido encontrado em tanques de cultivo da aquicultura e, embora existam alguns estudos sobre a fauna de parasitas neste hospedeiro, ainda há muito a ser relatado. Assim, o objetivo deste estudo é relatar o parasitismo por tricodinídeos em $L$. paradoxa, pois esses protozoários ciliados estão relacionados a lesões e mortalidade na piscicultura. Os peixes foram coletados de tanques experimentais, tiveram seu tegumento raspado e o muco resultante foi analisado sob um microscópio óptico para análises morfológicas e morfométricas em lâminas impregnadas com Nitrato de Prata e com Giemsa. Os espécimes encontrados foram identificados como Trichodina quelleni. Este é o primeiro registro deste parasita em L. paradoxa, e a segunda ocorrência de Trichodina quelenii em peixes cultivados no Brasil.

Palavras-chave: aquicultura, ectoparasitas, espécies invasoras, tricodinídeos.

\section{Introduction}

Trichodinids are ciliate protozoa with broad geographic distribution (Maciel et al., 2017). These parasites can establish a comensal or parasitic relationship with several vertebrate and a few invertebrate hosts, such as molluscs (Xu et al., 1999; Xu et al., 2000; Hertel et al., 2004;), crustaceans (Silva et al., 2009; West et al., 2016), amphibians (Dias et al., 2009), waterfowl (Carnaccini et al., 2016) and fishs (Valladão et al., 2013). These parasites are often observed in wild and cultured freshwater marine and freshwater fish (Tantry et al., 2016), affecting the skin, gills, urinary bladder, and reproductive system of fishes (Asmat, 2001).
Among the trichodinids, the genus Trichodina Ehrenberg, 1838 is the most diverse, with more than 200 species affecting fish (Asmat et al., 2005). In Brazil, studies regarding this group of parasites is recent but, due to the economical losses they can cause in fish farming, interest in these ciliates is increasing (Dias et al., 2009). To date, the species of tricodinids found in native Brazilian fish have been Trichodina heterodentata in Piaractus mesopotamicus and Prochilodus lineatus (Pádua et al., 2012; Valladão et al., 2014), Trichodina colisae in P. mesopotamicus and Piaractus brachypomus (Jerônimo et al., 2012), and Trichodina quelenii in Rhamdia quelen and Gymnotus sp. (Hashimoto et al., 2016). 
There are six species representing the lungfishs worldwide, with only one species registered in South America: Lepidosiren paradoxa Fitzinger, 1837 (Mesquita-Saad et al., 2002; Lainson and Ribeiro, 2006). The South American lungfish is native to the Amazon and Paraná-Paraguay basins. These animals inhabit lentic or low current environments, and support low concentrations of dissolved oxygen in water (Almeida-Val et al., 2016). There are a few records of parasitism in South American lungfish, with registers of Haemogregarina lepidosirenis (Jepps, 1927), Agarella gracilis (Dunkerly, 1915; Vita et al., 2004), and Eimeria lepidosirenis (Lainson and Ribeiro, 2006). Thus, the objective of this study is to report parasitism by trichodinids in this host, contributing to the knowledge of its parasite fauna.

\section{Material and Methods}

The studied specimens of Lepidosiren paradoxa came from the São Paulo State University (CAUNESP), on the Jaboticabal campus, state of São Paulo, Brazil. They were kept in $1000 \mathrm{~L}$ tanks at a water level of $1 \mathrm{~m}$ and controled temperature at $25^{\circ} \mathrm{C} \pm 1{ }^{\circ} \mathrm{C}$ at all times.

Body surface mucus smears were prepared on slides for fresh analysis under a microscope. The smears were dried at room temperature and impregnated with silver nitrate $2 \%$ to observe the adhesive disk morphology, as reported by Klein (1958). Other smears were stained with Giemsa for further study of nuclear structures, as suggested by Lom (1958).

The measurements of 100 specimens, obtained with the Moticam 2300 attached to a Nikon E200 microscope, were expressed in milimetes as arithmetic means \pm standard deviation followed, in parentheses, by the minimum and maximum values and the number of measured structures. In addition, schematic drawings of the denticles, as proposed by Van As and Basson (1989), were produced by means of vectorization, with CorelDraw ${ }^{\circledR}$ X5 software.

\section{Results}

The population of Trichodina sp. parasitizing L. paradoxa was classified as a medium-sized trichodinids, with the morphometric data presented in Table 1. The morphology of the trichodinids found has a broad blade, exceeding the axis $y+1$. Anterior margin slightly developed, almost parallel to the distal margin. Apophysis of the prominent blade. Posterior margin of the concave blade. Presence of posterior projection not well developed in some specimens. Well-developed central part with rounded end, located

Table 1. Morphometric data $(\mu \mathrm{m})$ of the trichodinids found in Lepidosiren paradoxa in comparison with the morphometric data of the first report of Trichodina quelenii in two different hosts, Rhamdia quelen and Gymnotus sp.

\begin{tabular}{|c|c|c|c|}
\hline \multirow{2}{*}{ Parasite species } & Trichodina quelenii & Trichodina quelenii & Trichodina quelenii \\
\hline & Present study & Hashimoto et al. (2016) & Hashimoto et al. (2016) \\
\hline Host & Lepidosiren paradoxa & Rhamdia quelen & Gymnotus sp. \\
\hline Infection site & Skin & Skin and gills & Skins and gills \\
\hline Local & São Paulo, Brazil & Santa Catarina, Brazil & Mato Grosso do Sul, Brazil \\
\hline Body $^{\mathrm{D}}$ & $55.0 \pm 2.5(51.2-59.6)$ & $54.4 \pm 3.7(49.7-61.5)$ & $51.2 \pm 4.6(41.1-62.3)$ \\
\hline Adhesive $\operatorname{disc}^{\mathrm{D}}$ & $45.2 \pm 2.6(41.8-49.5)$ & $45.3 \pm 3.8(41-52.8)$ & $41.2 \pm 3.9(31.8-50.2)$ \\
\hline Border membrane $^{\mathrm{W}}$ & $15.4 \pm 1.9(11.2-18.6)$ & $14.6 \pm 3.05(9.8-19.7)$ & $5.1 \pm 0.5(3.9-6.1)$ \\
\hline Denticulate ring ${ }^{\mathrm{D}}$ & $26.9 \pm 1.4(24.7-29.8)$ & $27.3 \pm 2.7(24.4-33.1)$ & $24.4 \pm 2.6(19.2-29.8)$ \\
\hline Number of denticles & $21 \pm 0.6(20-22)$ & $21 \pm 0.6(19-22)$ & $19.3 \pm 1.2(18-23)$ \\
\hline Pins per Denticle & $9.0 \pm 1.1(8-11)$ & $9.4 \pm 1.5(6-11)$ & $8.7 \pm 0.7(8-11)$ \\
\hline Denticle $^{\mathrm{L}}$ & $8.7 \pm 0.8(7.2-9.9)$ & $8.4 \pm 0.5(7.8-9.4)$ & $8.4 \pm 0.8(6.5-10.1)$ \\
\hline Blade $^{\mathrm{L}}$ & $3.9 \pm 0.9(2.3-5.4)$ & $4.3 \pm 0.5(3.9-5.5)$ & $3.7 \pm 0.5(2.6-4.9)$ \\
\hline Central portion ${ }^{\mathrm{W}}$ & $3.7 \pm 0.4(3.1-4.5)$ & $3.8 \pm 0.5(3.1-4.7)$ & $3.3 \pm 0.3(2.5-3.9)$ \\
\hline Ray $^{\mathrm{L}}$ & $6.4 \pm 1.3(3.9-8.4)$ & $6.7 \pm 1.3(4.7-8.6)$ & $6.5 \pm 0.8(3.9-8.3)$ \\
\hline $\operatorname{Span}^{\mathrm{L}}$ & $15.6 \pm 1.7(12.4-18.5)$ & $14.9 \pm 1.7(12.2-18.1)$ & $13.4 \pm 1.4(9.0-15.7)$ \\
\hline Ciliature & - & $367^{\circ}\left(364^{\circ}-373^{\circ}\right)$ & - \\
\hline Macronucleus $^{\mathrm{D}}$ & $50.5 \pm 4.8(39.8-67.5)$ & - & $46.2 \pm 6.3(29.8-59.2)$ \\
\hline Macronucleus $^{\mathrm{TH}}$ & $8.1 \pm 1.7(5.1-12.7)$ & - & $7.6 \pm 1.5(4.9-11.9)$ \\
\hline Macronucleus $^{\mathrm{LT}}$ & $12.6 \pm 5.9(3.2-24.7)$ & - & $11.5 \pm 3.5(6.0-20.2)$ \\
\hline Micronucleus $^{\mathrm{L}}$ & $3.8 \pm 1.1(2.1-6.7)$ & - & - \\
\hline Micronucleus ${ }^{\mathrm{W}}$ & $5.3 \pm 1.7(3.4-10.3)$ & - & - \\
\hline $\begin{array}{l}\text { Distance from the } \\
\text { Micronucleus to the end } \\
\text { of the Macronucleus }\end{array}$ & $20.2 \pm 6.2(6.4-31.8)$ & - & - \\
\hline
\end{tabular}

Measurement data were described as the mean \pm standard deviation (minimum - maximum; number of repetitions), $\mathrm{L}=$ length,${ }^{\mathrm{D}}=$ diameter, ${ }^{\mathrm{w}}=$ width, ${ }^{\mathrm{TH}}=$ thickness, ${ }^{\mathrm{LT}}=$ length between terminations of macronucleus. 

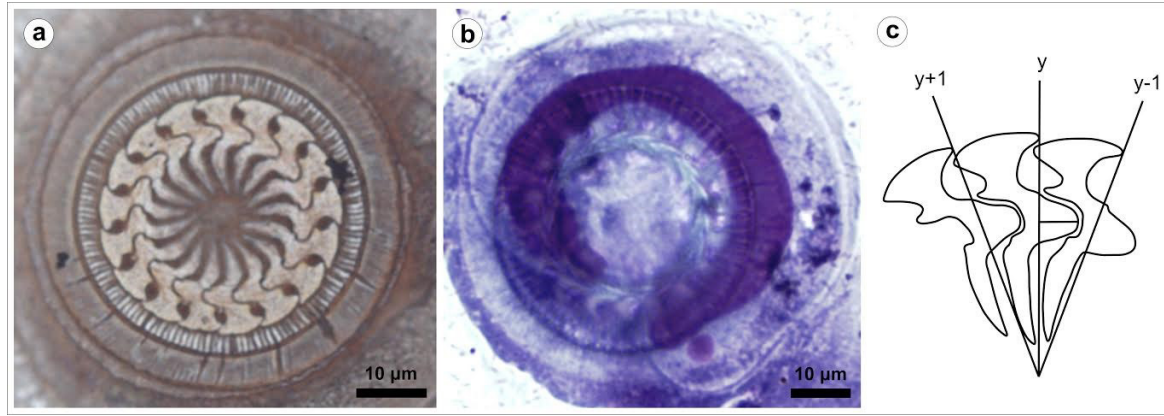

Figure 1. Trichodina quelenii stained with $2 \%$ silver nitrate (a); Trichodina quelenii stained with Giemsa with evidence of the macronucleus and micronucleus in position $+y(b)$; Schematic drawing of denticles (c).

between the axes and +1 and $y-1$. Discrete ray apophysis. Well-developed ray, thick, rounded end protruding posteriorly. The macronucleus is present in some trichodinids (51 specimens), as well as a micronucleus (21 specimens) located in the $+y$ position, the first description of this structure being in Trichodina quelenii (Figure 1). According to the morphology and morphometry the trichodinids found resemble the species Trichodina quelenii.

\section{Discussion}

There are no reports of any trichodinids in L. paradoxa so far. There is only a recent report of the genus Trichodina sp. infesting the African lungfish Protopterus annectens, but with low prevalence, $3.25 \%$ in the dry season and $2.83 \%$ in the rainy season (Omeji et al., 2017).

This is the second report of Trichodina quelenii, the first description being in the studied host. The first report was made in Brazil in two different hosts, Gymnotus sp. of natural environment and Rhamdia quelen coming from natural environment and fishfarm. (Hashimoto et al., 2016). The morphometric and morphologic descriptions are similar, even though we observed the presence of micronucleus in some specimens, a characteristic not reported in the original description of this species. Trichodinids are important parasites in the production systems of several species of fish, because the accumulation of organic matter in association with high storage densities causes an environmental imbalance that facilitates the multiplication and dissemination of the parasite. The genus Trichodina has been reported in several species of fish, causing damage to epithelial and epidermal cells (Ovcharenko, 2015), epithelial hypertrophy and vacuolar degeneration (Abdel-Baki et al., 2011), areas of inflammatory infiltration (Valladão et al., 2013), areas of desquamation and suction in the tegument (Valladão et al., 2016) caused by the excessive spoliation that allows the consequent installation of bacterial infections (Plumb, 1997) and mortality may occur in severely parasitized fish (Xu et al., 2015).

The South American lungfish is a highly resistant fish that supports extreme environmental conditions and is therefore found to be introduced into rivers, thus increasing its range, leading to risk for native and cultured fish populations (Arantes et al., 2016). Their presence inside tanks of aquatic organisms is an important source of multiplication and dispersion of trichodinids in breeding systems, thus becoming a potential risk of contagion in this situation. The first report of this parasite under cultivation was in Rhamdia quelen, in the state of Santa Catarina (Hashimoto et al., 2016), but possibly other reports may occur due to the restricted contact between L. paradoxa and other fish grown on a larger scale in Brazil, such as Nile tilapia (Oreochromis niloticus) or native fish such as pacu (Piaractus mesopotamicus) and tambaqui (Colossoma macropomum). Thus, further studies should be carried out to elucidate the possible biological role of parasitic dispersant of $L$. paradoxa, in commercial fish culture environments, in order to prevent diseases, reducing financial expenses due to producion losses or mortality caused by trichodinids parasitism.

\section{Acknowledgements}

The authors thank Dr. Glauber dos Santos Ferreira da Silva by fish donation.

\section{References}

ABDEL-BAKI, A.S., SAKRAN, T., FAYED, H. and ZAYED, E., 2011. Trichodina fahaka (Ciliophora: Peritrichia) in Tetradon fahaka from Nile River, Egypt: seasonality and histopathology. Scientific Research and Essays, vol. 6, no. 7, pp. 1583-1587.

ALMEIDA-VAL, V.M.F., NOZAWA, S.R., LOPES, N.P., ARIDE, P.H.R., MESQUITA-SAAD, L.S., SILVA, M.D.N.P. and VAL, A.L., 2016. Biology of the South American lungfish, Lepidosiren paradoxa. In: J.M. JORGENSEN and J. JOSS eds., The biology of lungfishes. New Hampshire: Science Publishers, pp. 129.

ARANTES, F.P., SANTOS, J.E. and BAZZOLI, N., 2016. Primeiro registro de Lepidosiren paradoxa, (Lepidosireniformes: Lepidosirenidae) para ao Rio Paraopeba, Bacia do Rio São Francisco, Brasil. Conexão Ciência (Online), vol. 11, no. 1, pp. 9-12. http://dx.doi.org/10.24862/cco.v11i1.402. 
ASMAT, G.S., 2001. Trichodina canningensis sp. n. (Ciliophora: Trichodinidae) from an Indian estuarine fish, Mystus gulio (Hamilton) (Bagridae). Acta Protozoologica, vol. 40, no. 2, pp. 147-152.

ASMAT, G.S., AFROZ, F. and MOHAMMAD, N., 2005. Four new species of Trichodina Ehrenberg, 1830 (Ciliophora: Trichodinidae) from Bangladesh fishes. Research Journal of Agriculture and Biological Sciences, vol. 1, no. 1, pp. 23-29.

CARNACCINI, S., LOWENSTINE, L.J., SENTÍES-CUÉ, C.G., NYAOKE, A., BLAND, M., BICKFORD, A.A., SHIVAPRASAD, H.L. and STOUTE, S.T., 2016. Trichodinosis associated with pathology of the reproductive tract in waterfowl. Avian Pathology, vol. 45, no. 4, pp. 418-425. http://dx.doi.org/10.1080/03079457. 2016.1153798. PMid:26926786.

DIAS, R.J., FERNANDES, N.M., SARTINI, B., DA SILVANETO, I.D. and D'AGOSTO, M., 2009. Occurrence of Trichodina heterodentata (Ciliophora: Trichodinidae) infesting tadpoles of Rhinella pombali (Anura: Bufonidae) in the Neotropical area. Parasitology International, vol. 58, no. 4, pp. 471-474. http:// dx.doi.org/10.1016/j.parint.2009.06.009. PMid:19580885.

DUNKERLY, J.S., 1915. Agarella gracilis, a new genus and species of Myxosporidian, parasitic in Lepidosiren paradoxa. Proceedings. Section A, Mathematical and Physical Sciences, vol. 19, pp. 213-219.

HASHIMOTO, G.S.O., MARCHIORI, N.C., PÁDUA, S.B., ISHIKAWA, M.M., GARCIA, J.R.E. and MARTINS, M.L., 2016. A new species of Trichodina Ehrenberg, 1830 (Ciliophora: Trichodinidae) from Rhamdia quelen (Siluriformes: Heptapteridae) -and Gymnotus sp. (Teleostei: Gymnotidae) in Brazil. Acta Parasitologica, vol. 61, no. 4, pp. 707-712. http://dx.doi. org/10.1515/ap-2016-0099. PMid:27787214.

HERTEL, L.A., BARBOSA, C.S., SANTOS, R.A.A.L. and LOKER, E.S., 2004. Molecular identification of symbionts from the pulmonate snail Biomphalaria glabrata in Brazil. The Journal of Parasitology, vol. 90, no. 4, pp. 759-763. http://dx.doi. org/10.1645/GE-223R. PMid:15357065.

JEPPS, M.W., 1927. Note on a haemogregarine in Lepidosiren paradoxa. Parasitology, vol. 19, no. 3, pp. 285-287. http://dx.doi. org/10.1017/S0031182000005722.

JERÔNIMO, G.T., MARCHIORI, N.D.C., PÁDUA, S.B.D., DIAS NETO, J., PILARSKI, F., ISHIKAWA, M.M. and MARTINS, M.L., 2012. Trichodina colisae (Ciliophora: Trichodinidae) new parasite records for two freshwater fish species farmed in Brazil. Revista Brasileira de Parasitologia Veterinária, vol. 21, no. 4, pp. 366-371. http://dx.doi.org/10.1590/S1984-29612012005000008. PMid:23207983.

KLEIN, B.M., 1958. The dry silver method and its proper use. The Journal of Eukaryotic Microbiology, vol. 5, no. 2, pp. 99-103.

LAINSON, R. and RIBEIRO, L., 2006. Eimeria lepidosirenis $\mathrm{n}$. sp.(Apicomplexa: Eimeriidae) of the South American lungfish Lepidosiren paradoxa (Osteichthyes: Dipnoi) from Amazonian Brazil. Memorias do Instituto Oswaldo Cruz, vol. 101, no. 3, pp. 327-329. http://dx.doi.org/10.1590/S0074-02762006000300018. PMid:16862331.

LOM, J., 1958. A contribution to the systematics and morphology of endoparasitic trichodinids from amphibians, with a proposal of uniform specific characteristics. The Journal of Eukaryotic Microbiology, vol. 5, no. 4, pp. 251-263.

MACIEL, P.O., GARCIA, F., CHAGAS, E.C., FUJIMOTO, R.Y. and TAVARES-DIAS, M., 2017. Trichodinidae in commercial fish in South America. Reviews in Fish Biology and Fisheries, vol. 28 , no. 1, pp. 33-56.

MESQUITA-SAAD, L.S.B., LEITÃO, M.A.B., PAULA-SILVA, M.N., CHIPPARI-GOMES, A.R. and ALMEIDA-VAL, V.M.F., 2002. Specialized metabolism and biochemical suppression during aestivation of the extant South American lungfish --Lepidosiren paradoxa. Brazilian Journal of Biology $=$ Revista Brasileira de Biologia, vol. 62, no. 3, pp. 495-501. http://dx.doi.org/10.1590/ S1519-69842002000300014. PMid:12530187.

OMEJI, S., OBANDE, R.A. and SOLOMON, S.G., 2017. Morphological and parasitological variations of African lungfish, Protopterus annectens in dry and rainy seasons. Journal of Research in Forestry Wildlife and Environment, vol. 9, no. 1, pp. 104-113.

OVCHARENKO, M., 2015. Microparasites of worldwide mullets. Annals of Parasitology, vol. 61, no. 4, pp. 229-239. PMid:26878619.

PÁDUA, S.B., MARTINS, M.L., CARRASCHI, S.P., CRUZ, C. and ISHIKAWA, M.M., 2012. Trichodina heterodentata (Ciliophora: Trichodinidae): a new parasite for Piaractus mesopotamicus (Pisces: Characidae). Zootaxa, vol. 3422, pp. 62-68.

PLUMB, J.A. 1997. Infections diseases of tilapia. In: B.A. COSTAPIERCE and J.E. RAKOCY, eds. Tilapia aquaculture in the Americas. Baton Rouge: World Aquaculture Society, pp. 212-218.

SILVA, W.M., ROCHE, K.F., DE VICENTE, F.S. and DELBEN, A.A., 2009. First record of the peritrich Trichodina diaptomi Basson and Van As, 1991 (Protozoa: Ciliophora) on a South American calanoid Notodiaptomus deitersi (Poppe, 1890) (Crustacea: Copepoda). The Journal of Eukaryotic Microbiology, vol. 56, no. 4, pp. 385-385. http://dx.doi.org/10.1111/j.1550-7408.2009.00414.x. PMid:19602084

TANTRY, T.A., NAZIR, R., CHISHTI, M.Z., AHMAD, F., DAR, G.H. and DAR, J.S., 2016. A report on the incidence of Trichodina heterodentata from fishes of Jammu, J\&K, India. Journal of Parasitic Diseases: Official Organ of the Indian Society for Parasitology, vol. 40, no. 2, pp. 524-527. http://dx.doi. org/10.1007/s12639-014-0538-z. PMid:27413332.

VALLADÃO, G.M., GALLANI, S.U., DE PÁDUA, S.B., MARTINS, M.L. and PILARSKI, F., 2014. Trichodina heterodentata (Ciliophora) infestation on Prochilodus lineatus larvae: a host-parasite relationship study. Parasitology, vol. 141, no. 5, pp. 662-669. http://dx.doi.org/10.1017/S0031182013001480. PMid:24476792.

VALLADÃO, G.M., PÁDUA, S.B., GALLANI, S.U., MENEZESFILHO, R.N., DIAS-NETO, J., MARTINS, M.L., ISHIKAWA, M.M. and PILARSKI, F., 2013. Paratrichodina africana (Ciliophora): a pathogenic gill parasite in farmed Nile tilapia. Veterinary Parasitology, vol. 197, no. 3-4, pp. 705-710. http:// dx.doi.org/10.1016/j.vetpar.2013.04.043. PMid:23731856.

VALLADÃO, G.M.R., ALVES, L.O. and PILARSKI, F., 2016. Trichodiniasis in Nile tilapia hatcheries: Diagnosis, parasite: host-stage relationship and treatment. Aquaculture (Amsterdam, Netherlands), vol. 451, pp. 444-450. http://dx.doi.org/10.1016/j. aquaculture.2015.09.030.

VAN AS, J.G. and BASSON, L., 1989. A further contribution to the taxonomy of the Trichodinidae (Ciliophora: Peritrichia) and a review of the taxonomic status of some fish ectoparasitic trichodinids. Systematic Parasitology, vol. 14, no. 3, pp. 157-179. http://dx.doi.org/10.1007/BF02187051.

VITA, P., CORRAL, L., MATOS, E. and AZEVEDO, C., 2004. Ultrastructural description of Agarella gracilis Dunkerly, 1915 
(Myxozoa, Chloromyxidae) parasite of the dipnoan Lepidosiren paradoxa from the River Amazon. European Journal of Protistology, vol. 40, no. 3, pp. 213-218. http://dx.doi.org/10.1016/j. ejop.2004.03.001.

WEST, D., BASSON, L. and VAN AS, J., 2016. Trichodina diaptomi Ciliophora: Peritrichia from two calanoid copepods from Botswana and South Africa, with notes on its life history. Acta Protozoologica, vol. 55, no. 3, pp. 161-171. https://doi.org /10.4467/16890027AP.16.016.5748.

XU, D.H., SHOEMAKER, C.A. and ZHANG, D., 2015. Treatment of Trichodina sp. reduced load of Flavobacterium columnare and improved survival of hybrid tilapia. Aquaculture Reports, vol. 2, pp. 126-131. http://dx.doi.org/10.1016/j.aqrep.2015.09.007.
XU, K., SONG, W. and WARREN, A., 1999. Trichodinid ectoparasites (Ciliophora: Peritrichida) from the gills of mariculture molluscs in China, with the descriptions of four new species of Trichodina Ehrenberg, 1838. Systematic Parasitology, vol. 42, no. 3, pp. 229-237. http://dx.doi.org/10.1023/A:1006071106844. PMid:10613541.

XU, K., SONG, W. and WARREN, A., 2000. Observations on trichodinid ectoparasites (Ciliophora: Peritricha) from the gills of maricultured molluscs in China, with descriptions of three new species of Trichodina Ehrenberg, 1838. Systematic Parasitology, vol. 45, no. 1, pp. 17-24. http://dx.doi.org/10.1023/A:1006284629307. PMid:10682920. 